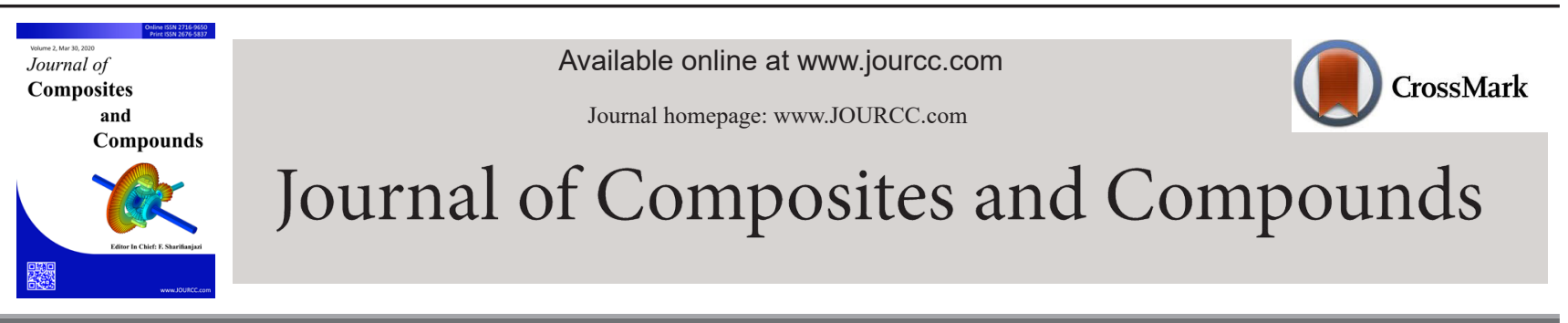

\title{
Bioactive glass coated zirconia for dental implants: A review
}

\author{
Kaiqiang Zhang ${ }^{a}$, Quyet Van Le ${ }^{b *}$ \\ a School of Chemistry and Chemical Engineering, Nanjing University, Nanjing 210023, China \\ ${ }^{b}$ Institute of Research and Development, Duy Tan University, Da Nang, 550000, Vietnam
}

\begin{abstract}
A B S T R A C T
Nowadays, zirconia has been favored greatly for dental implants; however its disadvantages such as poor mechan- Article history:

erate the formation of the bond between bone and implant. Hence, in this study, we introduce the novel zirconia/ Accepted 29 March 2020

bioactive glass composites with high mechanical strength and bioactivity to achieve the ideal implant in dentistry.

Furthermore, a review of bioactive glass coatings (i.e., 45S5 and 58S) on zirconia as well as surface modification

methods (i.e., sol-gel, laser cladding, plasma spraying, etc.) is provided.

(C)2020 JCC Research Group.

Peer review under responsibility of JCC Research Group
\end{abstract}

A R T I C L E IN F O R M A T I O N

ical properties and brittleness makes it unsuitable. On the other hand, bioactive glasses coating have been utilized Received 11 November 2019

on tougher substrates such as zirconia. Bioactive glass coatings can decrease the healing time and hence accel- Received in revised form 25 February 2020

\section{Keywords:}

Bioactive glass coating

Zirconia

Dental implants

Nanocomposites

Table of contents
1. Introduction
2. Zirconia implants
3. Bioactive glass in biomedical applications
3.1. $45 \mathrm{~S} 5$ bioglass
3.2 $58 \mathrm{~S}$ bioglass
4. Bioactive glass coatings
4. Conclusions and Future insights
4. Sol-gel 12

\section{Introduction}

In order to replace the missing teeth, oral implants can be considered a preferred option. This procedure was first proposed by Brånemark in the 1960s [1-5]. Many reports have covered the chemical and physical features of these implants including their design factor, surface structure and properties as well as implant microstructure. Moreover, many factors are believed to be important in the implant therapy prediction and clinical consequences.

Implants with good biocompatibility, sufficient corrosion and toughness can be categorized as ideal implants. Other ideal properties can be their great strength and resistance to fracture and wear [6-9]. The biological responses of dental implants as well as their chemical composition are the main properties that are significant in the categorization of these materials. Note that the principles of design of implant should be necessarily based on the material physical features [10].

Building fillers with the more similarity to human teeth is of great importance since current fillers cannot present enough functional and reinforcing impact for dental composites. Although, in the research of monomer structures as well as filler compositions, repair failure can still happen because of reconstruction fracture and the secondary-carriers [11-13].

Ceramics lack the electric current conduction and they can be applied for the production of purification and dissociation membranes of biological fluids in medical equipment. In this regard, they can be suitable to manufacture porous components for dosage drug administration. 
In medical field, they are appropriate to make prosthesis. Ceramics enjoy excellent integration capability with the tissue of human bone that can be considered as a superiority over the implants with metallic nature. Their biological inertness and electrical passivation have made ceramics a promising material for the medical equipment. In comparison with metallic implants, zirconia-based ceramics show minimum ion release and they are biologically inert [14-32].

Modern Ti implant technologies are being introduced owing to possible combination of immunologic and aesthetic aspects of $\mathrm{Ti}$ and $\mathrm{Ti}$ alloys. Nevertheless, these characteristics should be maintained during the improvement of this technology. To sustain these properties, dental implantology started to apply $\mathrm{Zr}$ as a desirable alternative to $\mathrm{Ti}$ [29].

$\mathrm{Ti}$ and $\mathrm{Zr}$ are similar in terms of biocompatibility and osteointegration. However, since $\mathrm{Zr}$ is more bioinert than $\mathrm{Ti}$, it is protected more against the attack by different organisms fermentation systems as well as degradation. This can present a minimum release of ion as compared with the metallic implants. It is well understood that the ion released from metallic implants can exert different unwanted effects including inflammatory, toxic, mutagenic and allergic reactions. A decrease in the lifetime and mechanical properties of the metallic implant can be made because of the in vivo corrosion of these implants [33].

The demand for zirconia dental implants is increasing recently. In comparison with the Ti dental implants, their increased esthetic featureowing to similarity to the human tooth color is the main benefit of these implants [34-45]. To enhance the zirconia bioactivity and morphological properties for proliferation, excellent cell attachment and the acceptable differentiation during the surrounded bone cure, many efforts have been made $[46,47]$.

In terms of advantages, some documents have mentioned that zirconia decreases the risk of explosive reactions in surrounding peri-implant tissues, because it can reduce the biofilm aggregation and bacteria adhesion $[32,36,48,49]$. On the other hand, titanium is grey and it can be corroded $[25,50]$. These two facts about $\mathrm{Ti}$, which surely can influence the appearance and health system, can provide aesthetic disadvantages that cannot be denied [46].Both of the materials would need 3 to 6 months prior to the fixation of complete prosthetic reconstruction [18, 51-56]. This time can be reduced by applying the bioactive glass coating. Furthermore, after implantation, the bone loss rate can be decreased, which is another benefit of these coatings [57-60].

\section{Zirconia implants}

Zirconia with better optical, aesthetic, mechanical and biological qualifications is a suitable substitute to traditional Ti implant system for oral recovery [61-64]; it is produced by the oxidation of zirconium [25, 27, 65-67]. Zirconium, which is a transition metal [56, 68] with greywhite color [69-73], can be used to make zirconia implant.

Segments of the metal implant can be uncovered by recession of gingiva and the loss of apical bone, which this can disclose a discolored overlying gingiva [74-77]. Thus, it would be possible to use the zirconia ceramics because they enjoy great aesthetic, biological and mechanical characteristics and they lack electrical corrosion. Polyethylene and Ti show more inflammatory reactions than zirconia. Less inflammatory re-

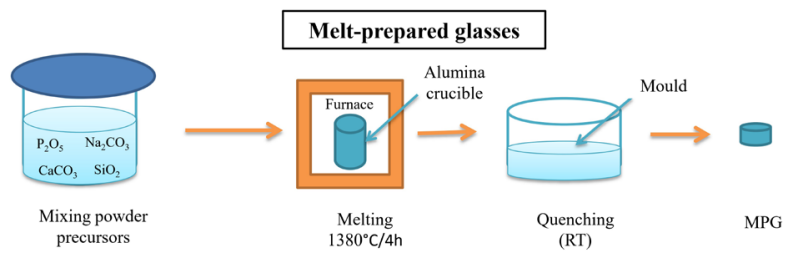

Fig. 1. Schematic of the melting process for preparing bioglass. sponse along with the lack of mutagenicity and toxicity in zirconia, can be considered as the most attractive zirconia properties [58].

\section{Bioactive glass in biomedical applications}

To regenerate the tissue, many medical approaches have been employed by bioglasses or bioceramics, which are manufactured in various phases and shapes. The capability of reaction with physiological media have been seen to be slower in bioceramics than that of bioactive glasses. This can result in better bonding with alive tissues and the formation of apatite layer. Hence, bioceramics require the special coated layer to improve their biomedical applications [78].

Because of the great bioactivity of BGs, they are one of the best biomaterials for renovation and bone repair. For the first time, they were introduced by Hench's team at the late 1960s [39, 79-81]. Moreover, by combining great mechanical strength and excellent bioactivity of BGs, they can be successfully used as coatings on inert substrates [82]. Reaction with the physiological fluids and the formation of chemical bonding between bones and bioglass can be occurred when bioglasses are implanted in the body [83-87]. A bioactive surface can be considered as important agent to avoid many simultaneous reactions, which take place between the implant and the targeted tissue at the implant surface [82].

Melting process, which starts from carbonates and oxides, is the most important technique of bioactive glass preparation. Then, sol-gel method with the ability of producing bioactive glasses with high bioactivity was introduced. Their increased bioactivity, which is presented by this method, resulted from the microstructural properties and tailored composition. Furthermore, melting approach needs to be processed at higher temperature as compared with the sol-gel methodology, which can limit or avoid the flux addition for sol-gel method [88]. The bioactive glass with its composite coatings can be classified as following categorization according to the coating structure.

\subsection{5 bioglass}

Ceramic $45 \mathrm{~S} 5 \mathrm{BG}$ with $24.5 \%$ sodium oxide, $45 \%$ silicon dioxides, $24.5 \%$ calcium dioxide and $6 \%$ phosphorus pentoxide have attracted the attentions of researchers as a biomaterial substance because of its osseointegration capability, bioactive surface and the ability of healing bone damages [89-91]. It can be prepared by melt-cast method with various crystallinity including amorphous and crystalline [92]. A schematic of melting process for producing melt-prepared glasses (MPG) is provided in Fig. 1.

In order to study the impact of bioactive glass $45 \mathrm{~S} 5$ crystallization on the degradation and constitution of apatite, Plewinski et al. [93], performed XRD analysis on the samples including samples treated by heat and amorphous samples. To guarantee the perfect amorphous sample crystallization, the heat-treatment was continued for 1 hour at $1000{ }^{\circ} \mathrm{C}$. They found that the apatite layer could be formed on this crystallized bioglass, unlike the amorphous ones, under these conditions.

\subsection{S bioglass}

$58 \mathrm{~S}$ bioactive glass is a great bioactive, biodegradable glass with the capability of bone bonding. Due to these qualifications, this bioactive glass, with $33 \%$ calcium oxide, $58 \%$ silicon dioxide $9 \%$ phosphorus pentoxide, has been favored as scaffold substance [94-97]. The reaction of $58 \mathrm{~S}$ bioactive glass with physiological fluids occurs after implantation quickly and it makes bond to the tissue of bone. This happens without inflammatory, toxicity and foreign-body reaction. The fast ionic dissolution as well as the hydroxyl-carbonated apatite layer formation was seen after the rapid in-vivo surface reactions. By release of calcium, silicon and phosphorous ions, the gene expression as well as the prolif- 


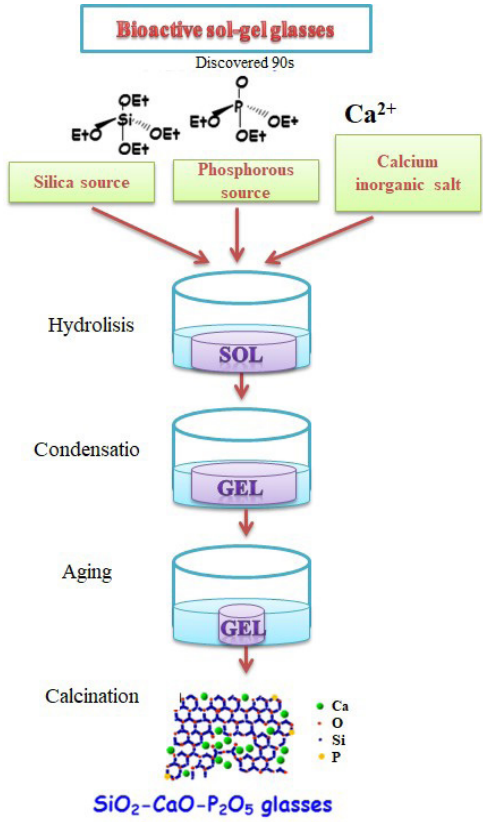

Fig. 2. Schematic illustration of the sol-gel process.

eration of osteoblast takes place to form the bone quickly.

58S-BG, produced by sol-gel approach, was used by Mokhtari et al. [98], to investigate the coatings of Chitosan-58S on nanotube of Titanium dioxide. A schematic illustration of sol-gel derived BGs is shown in Fig. 2. Based on the XRD results, the crystallization process of 58S-BG, which includes calcium silicate, calcium phosphate and Calcium Metasilicate, took place after the calcination at $1100^{\circ} \mathrm{C}$. This was continued by the structure transformation from amorphous to crystalline. Calcium Metasilicate was as the principal crystalline phase in the prepared powder. This demonstrated the intense interaction between osseous tissue and wollastonite.

To improve the bioactivity and mechanical properties of $58 \mathrm{~S}$ bioglass, Haftbaradaran et al. [99], examined the use of sol-gel prepared $58 \mathrm{~S}$ bioglass on fabricated-vitallium alloy. Based on the anticipations, the uncoated sample displayed a lower bioactivity as compared with the coated sample.

Faure et al. [100], used an organic acid catalyst to synthesize the 45S5 bioactive glass by a novel sol-gel approach. Instead of the conventional $\mathrm{HNO}_{3}$ with high concentration, $\mathrm{C}_{6} \mathrm{H}_{8} \mathrm{O}_{7}$ solution with a low concentration can be applied as a catalyst for hydrolysis reaction in the 45S5 bioactive glass preparation. Nevertheless, in this study, the bioactivity of the bioglass seems to be less than sol-gel bioactivity. In fact, sol-gel derived BG grains display extremely rough surfaces with great porosity. This, surely can present excellent exchange surface in physiological medium. Therefore, the sol-gel bioglass exchange surface can be more important than the exchange surface of the produced bioglass by the melting method.

In a study by Bui et al. [101], 58S-BG was prepared via a novel solgel technique. In this new approach, a quick transformation process of sol to gel, was conducted by the addition of ammonia solution. Next, the freeze-drying method was applied to dry prepared gel after $6 \mathrm{~h}$. During the in vitro evaluations, after 2 days, a clear dense HA layer was formed. This produced layer was as the bioactivity evidence of prepared bioglass.

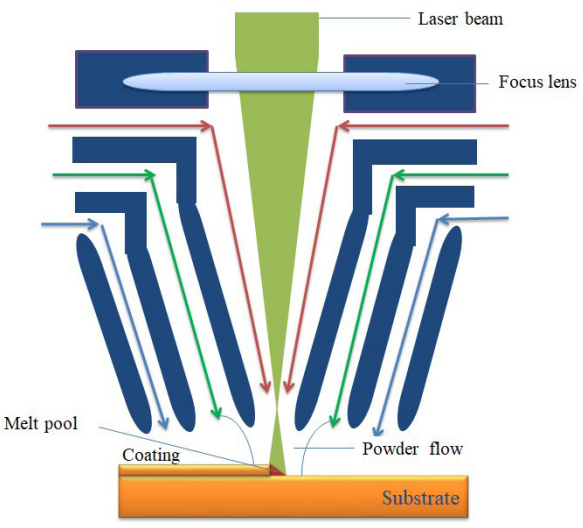

Fig. 3. Laser cladding process schematic for coating.

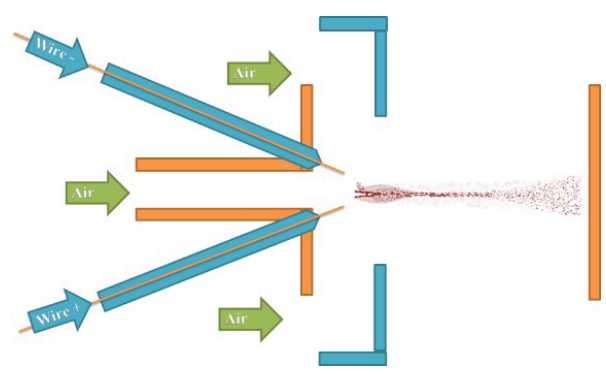

Fig. 4. Plasma spraying technique schematic illustration for deposition of BG

$$
\text { coatings. }
$$

\section{Bioactive glass coating}

Considering the investigations by many researchers, bioactive glasses possess potential of many wide applications such as the formation of HCA and bone, but their use as materials for coating, is more attractive than other applications, especially when they are used as an implant. Their mechanical integrity becomes important [102-105] when they are used as coating on tougher substrate [106-108]. The studies about coatings have proved that depending on the approach of coatings and deposition, the main chemical and physical characteristics will change [109113]. It was understood that chemical properties like long-term stability can also affect the bioactive glass coating performance [82].

Ceramics including $\mathrm{Ca}_{3}\left(\mathrm{PO}_{4}\right)_{2}, \mathrm{Zr}, \mathrm{Al}_{2} \mathrm{O}_{3}$ and $\mathrm{BGs}$ have gained more attentions recently for medical applications, since ceramic-based prostheses may provide a good opportunity to obtain more effective biomimetic properties [88].

\subsection{Laser cladding}

Diverse materials can be bonded together by laser cladding technique, which can be defined as a deposition method. The principal of this method is the coating of a substrate by a laser melted powder substance. However, various profiles from this method can be applied. Industrially, a coating can be produced by the powder injection onto the substrate and the melting of it by laser beam [82].

There is a possibility to introduce variability by the operator during the coating preparation. Laser cladding is able to remove them by increasing the products quality, because it can enhance the fabrication process speed automatically (Fig. 3) [39, 114-116].

Great pores interconnectivity in the outer layer of porous layer and the desirable joining quality at the interface of substrate and coating observed by micro-computed tomography in the study by Baino et al. 
[114]. They studied the laser cladding fabricated bioactive glass coating. The fabrication process was applied on the ceramic acetabular cups and the coatings can be made in a porous or pore-free form. The desired glass/ceramic joining was confirmed by indentation analysis.

To promote the osteointegration physiologically, a valuable technique is proposed, in which a bioactive coating deposition is applied on the surface of implant to make contact with bone. Baino et al. [117], used two dissimilar approaches (i.e. laser cladding and sponge replication) to produce the porous coatings of bioactive glass on the $\mathrm{Al}_{2} \mathrm{O}_{3}$ $\mathrm{ZrO}_{2}$ composite implant. The key for bone binding is the good ability of hydroxyapatite formation. An early evidence of modern porous glass coating biocompatibility and bioactive features was proved in this study.

Laser cladding process, which is believed to be effective in bioactive glass coatings, was applied by Montealegre et al. [118], to coat the bioactive glass on alumina/zirconia composite for orthopedic applications. Besides, for two different BGs, the technology could coat macroporous bioactive glass on alumina/zirconia composite. Moreover, the laser cladding process provides a possibility to achieve dense and homogeneous BG coating. The structure and formulation of the powders of BGs are easily translated to the $\mathrm{BG}$ coatings.

\subsection{Sol-gel}

The wet chemical technique of sol-gel shows high reactivity tobecause of providing a high surface area [119-121]. This high possibility of reactivity, surely provides a low temperature for this process. This means that the process does not need high temperature sintering. Moreover, it does not need high values of $\mathrm{pH}$ [122-124].

Sol-gel, as an affordable process, have become favorite technique of coating for glass-ceramic composite or bioactive glass, since it has various benefits i.e. coating layer uniformity, fairly great adhesion power on complex substrate, high composition accommodation [125-127], and desirable purity [128]. This method can be combined with other approaches easily. To fix the bioactive coating on the substrate of ceramic, a high temperature is needed after heat-treatment. Thus, in spite of the convenience of this method, a high temperature can involve the mismatch of the thermal expansion coefficient that can occur between the coating and substrate. This can be continued by the residual stress accumulation on interface or the change of coated glasses composition [129].

The fabrication of a broad bioactive glass range is possible by sol-gel method that has increased the success of this process. Besides, this benefit provides a possibility to make an improvement in cell adhesion and protein absorption, because the sol-gel process can give a high specific surface porous microstructure to the bioactive glass coating.

In vitro behavior of porous zirconia was investigated by Mesquita-Guimarães et al. [130] via MG-63 cells. During the condensation, the optimization of $58 \mathrm{~S}$ BG coating was followed by changing the number of immersions as well as controlling the sol-gel solution viscosity. In the 423-Z.BG structures, the improvement in the cell proliferation was occurred in the presence of $58 \mathrm{~S}$ BG bioactive glass. This enhancement, which was continued to maximum level, may reveal that the coating

Table 1

Various techniques used for bioactive glass coating on zirconia substrates.

\begin{tabular}{ccc}
\hline Methods & Pros. & Cons. \\
\hline Plasma spray & $\begin{array}{c}\text { A low probability of compromising glass bioactivity, a wide range } \\
\text { of coating materials }\end{array}$ & Weak adhesion between substrate and glass \\
Laser cladding & $\begin{array}{c}\text { The possibility of flat coating on surfaces with curved geometry } \\
\text { Multilayer coating, porous microstructure, versatile, large com- } \\
\text { positional range of bioactive glasses, controlled composition, and } \\
\text { homogeneity }\end{array}$ & $\begin{array}{c}\text { Need surface pre-treatment, lack of uniformity } \\
\text { hol the difference in CTE between substrate and coating, post heat treatment } \\
\text { introduces internal stress }\end{array}$ \\
Enameling & Large range of thickness, versatile, cheap simple & $\begin{array}{c}\text { Thermal residual stress, the formation of chemical by-product, metal degradation, } \\
\text { glass crystallization, compositional gradient }\end{array}$ \\
\hline
\end{tabular}

affects the activity of cells positively to make the extracellular matrix. ratio of $\mathrm{Ca} / \mathrm{P}$ on a Zirconia-3\% Yttria substrate to prepare the extremely bioactive glass coating. The prepared coatings in this study, had thickness of $345 \mu \mathrm{m}$ with crack-free surface, which are the representative of great glass/substrate biocompatibility in terms of the matching of expansion coefficient.

In another study, Lin et al. [131], produced mesoporous bioglass (MBGs), which were coated by $\mathrm{ZrO}_{2}$ using dip-coating method to apply in the engineering process of bone tissue. To remove the excess sols, immersed-samples were centrifuged ( $30 \mathrm{~s}$ and $500 \mathrm{rpm}$ ). The results showed desired cell viability and biocompatibility and no cytotoxicity.

The dip-coating method consists of three steps: (i) samples dipping, (ii) withdrawing them and (iii) drying. After immersing the samples in the solution, they should be withdrawn in a constant speed. In order to guarantee the spread of equal thickness all over the substrate surface, it is important to have a steady speed.

The application of the dip-coating technique under extreme conditions as well as surface thickness distribution was studied by Faustino et al. [132] by making some models. The study and optimization of sol- gel method is required, since preparation, curing as well as aging time of sol-gel approaches are time consuming. Moreover, during heat-treatment process, there is the possibility of phase separation. Thus, industrially, these can make limitations in production process.

\subsection{Plasma spray}

Recently, the deposition of bioactive glass coatings, has been applied by standard spray technique in various studies (Fig. 4). The suspension plasma spray (a modern spray method, SPS) is newly introduced, in which a liquid suspension can be applied as a substitute of a dry powder, as feedstock [133].

Cattini et al. [133], investigated the processing parameters of SPS on mechanical properties, in-vitro condition and microstructure. Micro-size powder suspension was used to produce a bioactive coating. A preliminary screening of processing parameters displayed that the spray distance, the flow rate of $\mathrm{H}_{2}$ and the inputs of plasma electric power may affect the microstructure. The optimum and suitable hydrogen flow rate, power and spray distance were $7.5 \mathrm{slpm}, 36-40 \mathrm{~kW}$ and 50-70 mm, respectively, for biomedical applications.

Calvo et al. [134], melt-quenched the powders of $45 \mathrm{~S} 5$ bioactive glass consisting of $24.5 \%$ calcium oxide, $45 \%$ silicon dioxide, $6 \%$ phosphorus pentoxide and $24.5 \%$ sodium oxide. They investigated the use of atmospheric plasma spraying (PS) on the coatings of 45S5 bioactive glass. They milled the obtained frit via two dissimilar methods including wet and dry milling. To achieve a powder, consisting of porous agglomerates, the primer method was continued by spray drying while the latter should be followed by sieving.

Great surface properties, which can guarantee the effective contact with body fluid and excellent adhesion power to the substrate, was obtained by prepared coatings through atmospheric PS. All of the feed-
Araujo et al. [33], used a novel bioactive glass layer including a low 
stocks showed amorphous phase.

Joulia et al. [135], studied the mechanisms of deposition in solution precursor plasma spray (SPPS) and SPS for yttria stabilized zirconia (YSZ). Their investigated the mechanisms of deposition in suspension and solution precursor plasma spraying by studying the characteristics of individual YSZ lamellae and of complete coatings. They found that plasma-spraying using liquid feedstock could be a promising method for depositing finely structured ceramic coatings. Table 1 summerizes various techniques used for bioactive glass coating on zirconia substrates

\subsection{Enameling}

Enameling is a kind of conventional treatment of surface, with the benefits of facile operation, inexpensive processing system that can provide the optimization possibility via altering the processing parameters [136-138]. Although this technique can involve the glass frit layer fusing, the applied metal substrate for coating can control the introduction of a lower melting frit. The combination of the tailored-composite glass and the enameling method has been proved to be a suitable option for the fabrication process of a bioactive glass layer. This can be done onto a bioinert substrate of metal, which has the great adherence, bioactivity and thermal expansion coefficient.

The enameling approach is facile and affordable, and it is usually used for coating a ceramic or metal by a glass. In this technique, the deposition of a suspension of powder glass or a thin glass layer onto a substrate of metal or ceramic could be followed by glazing the glass by a suitable heat treatment.

In the zirconia, alumina and ceramic composites coating, the enameling by the substrates, which are made by ceramic, has showed more promising results compared to the metal substrates. Moreover, the proper engineering of processing system and glass structure can transfer the surface layer to a coating with functionally graded and enhanced mechanical properties [82].

\section{Conclusions and future insights}

The bioactive glasses are favored greatly due to their potential for biomedical applications such as improving the bond strength in formation of bone, accelerating healing time, etc. these characteristics have made them good candidates to be used as coating on appropriate substrate such as $\mathrm{ZrO}_{2}$-based dental implants. This is because of poor mechanical properties and brittleness of zirconia. Thus, the composite of BGs and $\mathrm{ZrO}_{2}$-based material would be great for biological applications. Hence, a thorough review was performed about these implant composites. It was found that, through coating of BGs on zirconia substrate, reinforcing properties especially in dental implants would be obtained.

Coatings are the advantageous and extensive field for medical applications. Therefore, we can fabricate special coatings to promote the zirconia implants advantages and also decrease the risk factors and possibility of dental implant failure.

\section{Acknowledgments}

The authors received no financial support for the research, authorship and/or publication of this article.

\section{Conflict of Interest}

All authors declare no conflicts of interest in this paper.

\section{REFERENCES}

[1] S. Mohammadpour, S.J.I.j.o.e. Khorramymehr, technology, Comparing oneand two-piece dental abutments under dynamic loading: A 3-D finite element analysis, 11 (2019) 73-79.

[2] A. TV, SIGN IN/REGISTER, Compendium (2020).
[3] M. Assery, A 22-Year Follow Up of Immediate Implant Placement without Bone Augmentation: A Case Series Study, Journal of Prosthodontics 29(2) (2020) 101-106.

[4] Z.M. Al-Sadah, M.S. AlShakhas, Osseous Integration After Exenteration, in: T.E. Johnson (Ed.), Anophthalmia : The Expert's Guide to Medical and Surgical Management, Springer International Publishing, Cham, 2020, pp. 107-126.

[5] B.R. Chrcanovic, J. Kisch, T. Albrektsson, A. Wennerberg, A retrospective study on clinical and radiological outcomes of oral implants in patients followed up for a minimum of 20 years, Clinical Implant Dentistry and Related Research 20(2) (2018) 199-207

[6] K.E. Dux, Implantable Materials Update, Clinics in Podiatric Medicine and Surgery 36(4) (2019) 535-542.

[7] S.D. Shah, Implant Strength After Implantoplasty, The Ohio State University, 2019.

[8] M.D. Fahmy, A. Gupta, A. Guentsch, A. Peisker, Materials Used Intraoper-atively During Oral and Maxillofacial Surgery Procedures, in: L. Tayebi (Ed.), Applications of Biomedical Engineering in Dentistry, Springer International Pub-lishing, Cham, 2020, pp. 21-42.

[9] R. Das, C. Bhattacharjee, 16 - Titanium-based nanocomposite materials for dental implant systems, in: A.M. Asiri, Inamuddin, A. Mohammad (Eds.), Appli-cations of Nanocomposite Materials in Dentistry, Woodhead Publishing, London, 2019, pp. 271-284.

[10] R.B. Osman, M.V. Swain, A critical review of dental implant materials with an emphasis on titanium versus zirconia, Materials 8(3) (2015) 932-958.

[11] J. Wu, X. Xie, H. Zhou, F.R. Tay, M.D. Weir, M.A.S. Melo, T.W. Oates, N. Zhang, Q. Zhang, H.H.K. Xu, Development of a new class of self-healing and therapeutic dental resins, Polymer Degradation and Stability 163 (2019) 87-99.

[12] X. Zhou, X. Huang, M. Li, X. Peng, S. Wang, X. Zhou, L. Cheng, Devel-opment and status of resin composite as dental restorative materials, Journal of Applied Polymer Science 136(44) (2019) 48180.

[13] H. Chen, R. Wang, L. Qian, H. Liu, J. Wang, M. Zhu, Surface modification of urchin-like serried hydroxyapatite with sol-gel method and its application in dental composites, Composites Part B: Engineering 182 (2020) 107621.

[14] A. Mzyk, G. Imbir, K. Trembecka-Wójciga, J.M. Lackner, H. Plutecka, E. Jasek-Gajda, J. Kawałko, R. Major, Rolling or Two-Stage Aggregation of Platelets on the Surface of Thin Ceramic Coatings under in Vitro Simulated Blood Flow Conditions, ACS Biomaterials Science \& Engineering 6(2) (2020) 898-911.

[15] J. Mallya, N. DuVall, J. Brewster, H. Roberts, Endodontic Access Effect on Full Contour Zirconia and Lithium Disilicate Failure Resistance, Operative Dentistry 45(3) (2020) 276-285.

[16] P. Maló, M. Nunes, M. de Araújo Nobre, A. Lopes, A. Ferro, Extramaxillary Zygomatic Implants, in: J. Chow (Ed.), Zygomatic Implants: Optimization and Innovation, Springer International Publishing, Cham, 2020, pp. 87-107.

[17] O. Jung, D. Porchetta, M.-L. Schroeder, M. Klein, N. Wegner, F. Walther, F. Feyerabend, M. Barbeck, A. Kopp, In Vivo Simulation of Magnesium Degradabil-ity Using a New Fluid Dynamic Bench Testing Approach, International Journal of Molecular Sciences 20(19) (2019).

[18] N. Shrivastava, H. Barbosa, K. Ali, S.K. Sharma, Materials for Solar Cell Ap-plications: An Overview of TiO2, ZnO, Upconverting Organic and Polymer-Based Solar Cells, in: S.K. Sharma, K. Ali (Eds.), Solar Cells: From Materials to Device Technology, Springer International Publishing, Cham, 2020, pp. 55-78. [19] A.I. Kozelskaya, E.N. Bolbasov, A.S. Golovkin, A.I. Mishanin, A.N. Viknianshchukb, E.V. Shesterikov, A.H. Ashrafov, V.A. Novikov, S.I. Tverdokhlebov, Modification of the zirconia ceramics by different calcium phosphate coatings: comparative study, arXiv preprint arXiv:1712.00944 (2017).

[20] L. Grima, M. Díaz-Pérez, J. Gil, D. Sola, I.J. Peña, Generation of a Porous Scaffold with a Starting Composition in the CaO-SiO2-MgO-P2O5 System in a Simulated Physiological Environment, Applied Sciences 10(1) (2019).

[21] J.L. Guo, T.C. Piepergerdes, A.G. Mikos, Chapter 6 - Bone graft engineering: Composite scaffolds, in: H. Alghamdi, J. Jansen (Eds.), Dental Implants and Bone Grafts, Woodhead Publishing, London, 2020, pp. 159-181.

[22] M. Wöltje, R. Brünler, M. Böbel, S. Ernst, S. Neuss, D. Aibibu, C. Cherif, Functionalization of Silk Fibers by PDGF and Bioceramics for Bone Tissue Regeneration, 10(1) (2020) 8 .

[23] A. Ralls, P. Kumar, M. Misra, P.L. Menezes, Material Design and Surface Engineering for Bio-implants, JOM 72(2) (2020) 684-696.

[24] A. Bharadwaz, A.C. Jayasuriya, Recent trends in the application of widely used natural and synthetic polymer nanocomposites in bone tissue regeneration, Materials Science and Engineering: C 110 (2020) 110698.

[25] S.J. Sadowsky, Has zirconia made a material difference in implant prostho-dontics? A review, Dental Materials 36(1) (2020) 1-8.

[26] K.-y. Cheng, V. Gopal, M. McNallan, G. Manivasagam, M.T. Mathew, En- 
hanced Tribocorrosion Resistance of Hard Ceramic Coated Ti-6Al-4V Alloy for Hip Implant Application: In-Vitro Simulation Study, ACS Biomaterials Science \& Engineering 5(9) (2019) 4817-4824.

[27] M. Giri, K. Sabapathy, B. Govindasamy, H. Rajamurugan, Evaluation of in-sertion torque and surface integrity of zirconia-coated titanium mini screw implants, Journal of the World Federation of Orthodontists 9(1) (2020) 13-17.

[28] D. Faria, S. Madeira, M. Buciumeanu, F.S. Silva, O. Carvalho, Novel laser textured surface designs for improved zirconia implants performance, Materials Science and Engineering: C 108 (2020) 110390.

[29] Z. Özkurt, E. Kazazoğlu, Zirconia dental implants: a literature review, Journal of oral implantology 37(3) (2011) 367-376.

[30] S. Amtul Haseeb, S.M. Abdul Khader, B. Satish Shenoy, Y.G. Naveen, P. Giridhar Kamath, K.C. Vinaya, Comparative evaluation of stress distribution in bone surrounding implant using different implant biomaterials: A 3DFEA study, Journal of Computational Methods in Sciences and Engineering 19 (2019) 523-532.

[31] E. Kontonasaki, P. Giasimakopoulos, A.E. Rigos, Strength and aging resis-tance of monolithic zirconia: an update to current knowledge, Japanese Dental Science Review 56(1) (2020) 1-23.

[32] A.W. Suci Dharmayanti, R. Dubey, N.K. Dubey, W.-P. Deng, Chapter 26 - Implant surface modification strategies through antibacterial and bioactive com-ponents, in: K. Pal, I. Banerjee, P. Sarkar, D. Kim, W.-P. Deng, N.K. Dubey, K. Majumder (Eds.), Biopolymer-Based Formulations, Elsevier2020, pp. 647-673.

[33] M. Araújo, M. Miola, A. Venturello, G. Baldi, J. Pérez, E. Verné, Glass coatings on zirconia with enhanced bioactivity, Journal of the European Ceramic Soci-ety 36(13) (2016) 3201-3210.

[34] N. Kong, A. Chen, W. Yan, H. Zhang, Ceramic implant fracture: A clinical report, The Journal of prosthetic dentistry 122(5) (2019) 425-429.

[35] B. Mansfield, S. Torres, T. Yu, D. Wu, A Review on Additive Manufacturing of Ceramics, ASME 2019 14th International Manufacturing Science and Engineering Conference, American Society of Mechanical Engineers Digital Collection, 2019. [36] X. He, F.-X. Reichl, S. Milz, B. Michalke, X. Wu, C.M. Sprecher, Y. Yang, M. Gahlert, S. Röhling, H. Kniha, R. Hickel, C. Högg, Titanium and zirconium release from titanium- and zirconia implants in mini pig maxillae and their toxicity in vitro, Dental Materials 36(3) (2020) 402-412.

[37] S. Madeira, A. Barbosa, C.G. Moura, M. Buciumeanu, F.S. Silva, O. Carval-ho, Aunps and Agups-functionalized zirconia surfaces by hybrid laser technology for dental implants, Ceramics International 46(6) (2020) 7109-7121.

[38] M. Koller, E. Steyer, K. Theisen, S. Stagnell, N. Jakse, M. Payer, Two-piece zirconia versus titanium implants after 80 months: Clinical outcomes from a prospective randomized pilot trial, Clinical Oral Implants Research 31(4) (2020) 388396.

[39] H. Gul, M. Khan, A.S. Khan, 3 - Bioceramics: types and clinical applications, in: A.S. Khan, A.A. Chaudhry (Eds.), Handbook of Ionic Substituted Hydroxyap-atites, Woodhead Publishing, London, 2020, pp. 53-83.

[40] Y. Liu, B. Rath, M. Tingart, J. Eschweiler, Role of implants surface modifi-cation in osseointegration: A systematic review, Journal of Biomedical Materials Research Part A 108(3) (2020) 470-484

[41] P. Tidehag, Z. Shen, Digital dentistry calls the change of ceramics and ceramic processes, Advances in Applied Ceramics 118(1-2) (2019) 83-90.

[42] Y.S. Soo, N. Silikas, J. Satterthwaite, Measurement of Fracture Strength of Zirconia Dental Implant Abutments with Internal and External Connections Using Acoustic Emission, Materials 12(12) (2019).

[43] S. Attia, H. Schaaf, T. El Khassawna, D. Malhan, K. Mausbach, H.-P. How-aldt, P. Streckbein, Oral Rehabilitation of Hypodontia Patients Using an Endosse-ous Dental Implant: Functional and Aesthetic Results, Journal of Clinical Medi-cine 8(10) (2019) 1687.

[44] G. Bryce, N. Diessner, K. Hemmings, N. MacBeth, Solutions for implants placed with prosthetic inconvenience, Dental Update 46(11) (2019) 1003-1014.

[45] M. Uno, Y. Doi, Y. Yokokawa, H. Kawaki, T. Oka, Y. Tamaki, H. Ishigami, Investigating the effectiveness of ceramic materials, particularly zirconium oxide, and the advantages the white metal holds over traditional materials used in dentist-ry, Impact 2019(2) (2019) 68-70.

[46] F.H. Schünemann, M.E. Galárraga-Vinueza, R. Magini, M. Fredel, F. Silva, J.C. Souza, Y. Zhang, B. Henriques, Zirconia surface modifications for implant dentistry, Materials Science and Engineering: C 98 (2019) 1294-1305.

[47] J. Mesquita-Guimarães, R. Detsch, A.C. Souza, B. Henriques, F.S. Silva, A.R. Boccaccini, O. Carvalho, Cell adhesion evaluation of laser-sintered HAp and 45S5 bioactive glass coatings on micro-textured zirconia surfaces using MC3T3-E1 osteoblast-like cells, Materials Science and Engineering: C 109 (2020) 110492.

[48] S. Hussain, E. Aneggi, S. Briguglio, M. Mattiussi, V. Gelao, I. Cabras, L. Zorzenon, A. Trovarelli, D. Goi, Enhanced ibuprofen removal by heteroge-neous-Fenton process over $\mathrm{Cu} / \mathrm{ZrO}_{2}$ and $\mathrm{Fe} / \mathrm{ZrO}_{2}$ catalysts, Journal of Envi- ron-mental Chemical Engineering 8(1) (2020) 103586.

[49] B. Mjöberg, Is early migration enough to explain late clinical loosening of hip prostheses?, EFORT Open Reviews 5(2) (2020) 113-117.

[50] F.H. Schünemann, M.E. Galárraga-Vinueza, R. Magini, M. Fredel, F. Silva, J.C.M. Souza, Y. Zhang, B. Henriques, Zirconia surface modifications for implant dentistry, Materials Science and Engineering: C 98 (2019) 1294-1305.

[51] A. Roccuzzo, S. Marchese, N. Worsaae, S.S. Jensen, The sandwich osteotomy technique to treat vertical alveolar bone defects prior to implant placement: a sys-tematic review, Clinical Oral Investigations 24(3) (2020) 1073-1089.

[52] M. Chiapasco, G. Tommasato, D. Palombo, M. Del Fabbro, A retrospective 10-year mean follow-up of implants placed in ridges grafted using autogenous mandibular blocks covered with bovine bone mineral and collagen membrane, Clinical Oral Implants Research 31(4) (2020) 328-340.

[53] E. Askari, I.F. Cengiz, J.L. Alves, B. Henriques, P. Flores, M.C. Fredel, R.L. Reis, J.M. Oliveira, F.S. Silva, J. Mesquita-Guimarães, Micro-CT based finite element modelling and experimental characterization of the compressive mechanical properties of 3-D zirconia scaffolds for bone tissue engineering, Journal of the Mechanical Behavior of Biomedical Materials 102 (2020) 103516.

[54] Y. Cao, T. Shi, C. Jiao, H. Liang, R. Chen, Z. Tian, A. Zou, Y. Yang, Z. Wei, C. Wang, L. Shen, Fabrication and properties of zirconia/hydroxyapatite compos-ite scaffold based on digital light processing, Ceramics International 46(2) (2020) 2300-2308.

[55] V. Lalzawmliana, A. Anand, M. Roy, B. Kundu, S.K. Nandi, Mesoporous bioactive glasses for bone healing and biomolecules delivery, Materials Science and Engineering: C 106 (2020) 110180

[56] A.-M. Pobloth, M.J. Mersiowsky, L. Kliemt, H. Schell, A. Dienelt, B.M. Pfitzner, R. Burgkart, R. Detsch, D. Wulsten, A.R. Boccaccini, G.N. Duda, Bioac-tive coating of zirconia toughened alumina ceramic implants improves cancellous osseointegration, Scientific Reports 9(1) (2019) 16692.

[57] A. Kirsten, A. Hausmann, M. Weber, J. Fischer, H. Fischer, Bioactive and thermally compatible glass coating on zirconia dental implants, Journal of dental research 94(2) (2015) 297-303.

[58] M. Roy, A. Pompella, J. Kubacki, A. Piosik, B. Psiuk, J. Klimontko, J. Szade, R.A. Roy, W. Hedzelek, Photofunctionalization of dental zirconia oxide: Surface modification to improve bio-integration preserving crystal stability, Colloids and Surfaces B: Biointerfaces 156 (2017) 194-202.

[59] M.S. Abd-Elwahed, A. Wagih, I.M.R. Najjar, Correlation between micro/ na-no-structure, mechanical and tribological properties of copper-zirconia nanocom-posites, Ceramics International 46(1) (2020) 56-65.

[60] Z. Fattahi, S.A. Sajjadi, A. Babakhani, F. Saba, Ni-Cr matrix composites re-inforced with nano- and micron-sized surface-modified zirconia: Synthesis, micro-structure and mechanical properties, Journal of Alloys and Compounds 817 (2020) 152755 .

[61] A. Katsavochristou, M. Sierraalta, B. Saglik, D. Koumoulis, F. George, M. Razzoog, Implant Angulation Effect on the Fracture Resistance of Monolithic Zirconia Custom Abutments: An In Vitro Study, Journal of Prosthodontics 29(5) (2020) 394-400

[62] R. Pilo, M. Folkman, A. Arieli, S. Levartovsky, Marginal Fit and Retention Strength of Zirconia Crowns Cemented by Self-adhesive Resin Cements, Opera-tive Dentistry 43(2) (2018) 151-161.

[63] K.I. Afrashtehfar, M. Del Fabbro, Clinical performance of zirconia implants: A meta-review, The Journal of Prosthetic Dentistry 123(3) (2020) 419-426.

[64] K. Sivaraman, A. Chopra, A.I. Narayan, D. Balakrishnan, Is zirconia a viable alternative to titanium for oral implant? A critical review, Journal of Prosthodontic Research 62(2) (2018) 121-133.

[65] Y. Iinuma, M. Hirota, T. Hayakawa, C. Ohkubo, Surrounding Tissue Response to Surface-Treated Zirconia Implants, Materials 13(1) (2019) 30.

[66] M. AlAmar, F. Alqahtani, Effect of Different Implant-Abutment Connection Materials on the Fracture Resistance of Zirconia Abutments, Journal of Oral Implantology 46(2) (2020) 88-92.

[67] D.-J. Lee, J.-S. Ryu, M. Shimono, K.-W. Lee, J.-M. Lee, H.-S. Jung, Differen-tial Healing Patterns of Mucosal Seal on Zirconia and Titanium Implant, Frontiers in Physiology 10(796) (2019).

[68] K. Mizuno, A. Torosian, S. Jivraj, Laboratory Fabrication of Full-Arch Im-plant-Supported Restorations, in: S. Jivraj (Ed.), Graftless Solutions for the Eden-tulous Patient, Springer International Publishing, Cham, 2018, pp. 261-320. [69] U. Schepke, M.M.M. Gresnigt, W.R. Browne, S. Abdolahzadeh, J. Nijkamp, M.S. Cune, Phase transformation and fracture load of stock and CAD/CAM-customized zirconia abutments after 1 year of clinical function, Clinical Oral Implants Research 30(6) (2019) 559-569.

[70] E. Schwarzer, S. Holtzhausen, U. Scheithauer, C. Ortmann, T. Oberbach, T. Moritz, A. Michaelis, Process development for additive manufacturing of 
func-tionally graded alumina toughened zirconia components intended for medical im-plant application, Journal of the European Ceramic Society 39(2) (2019) 522-530.

[71] H. Cai, J. Chen, C. Li, J. Wang, Q. Wan, X. Liang, Quantitative discoloration assessment of peri-implant soft tissue around zirconia and other abutments with different colours: A systematic review and meta-analysis, Journal of Dentistry 70 (2018) 110-117.

[72] F. Tabatabaian, Color in Zirconia-Based Restorations and Related Factors: A Literature Review, Journal of Prosthodontics 27(2) (2018) 201-211.

[73] A. Wachtel, T. Zimmermann, M. Sütel, U. Adali, M. Abou-Emara, W.-D. Müller, S. Mühlemann, A.D. Schwitalla, Bacterial leakage and bending moments of screw-retained, composite-veneered PEEK implant crowns, Journal of the Me-chanical Behavior of Biomedical Materials 91 (2019) 32-37.

[74] M. Boniecki, T. Sadowski, P. Gołębiewski, H. Węglarz, A. Piątkowska, M. Romaniec, K. Krzyżak, K. Łosiewicz, Mechanical properties of alumina/zirconia composites, Ceramics International 46(1) (2020) 1033-1039.

[75] Z. Ma, Z. Wang, X. Wang, T. Yu, Effects of laser-assisted grinding on surface integrity of zirconia ceramic, Ceramics International 46(1) (2020) 921-929.

[76] D. Silva-Herzog Rivera, A. Pozos-Guillen, A. Aragón-Piña, B.I. Cerda-Cristerna, D. Masuoka-Ito, L.O. Sánchez-Vargas, Glass coatings to enhance the interfacial bond strength between veneering ceramic and zirconia, Odontology 108(3) (2020) 415-423.

[77] M. Ji, J. Xu, M. Chen, M. El Mansori, Enhanced hydrophilicity and tribo-logical behavior of dental zirconia ceramics based on picosecond laser surface texturing, Ceramics International 46(6) (2020) 7161-7169.

[78] S.A. Omar, Y. Castro, J. Ballarre, W.H. Schreiner, A. Durán, S.M. Ceré, Mag-nesium alloys implants coated with 58S sol-gel bioactive glass to retard first stage corrosion, Corrosion 73(12) (2017) 1448-1460.

[79] M. Abdelraof, M.S. Hasanin, M.M. Farag, H.Y. Ahmed, Green synthesis of bacterial cellulose/bioactive glass nanocomposites: Effect of glass nanoparticles on cellulose yield, biocompatibility and antimicrobial activity, International Journal of Biological Macromolecules 138 (2019) 975-985.

[80] Q. Nawaz, M.A. Ur Rehman, J.A. Roether, L. Yufei, A. Grünewald, R. Detsch, A.R. Boccaccini, Bioactive glass based scaffolds incorporating gelatin/manganese doped mesoporous bioactive glass nanoparticle coating, Ceramics International 45(12) (2019) 14608-14613.

[81] S. Ali, I. Farooq, A.M. Al-Thobity, K.S. Al-Khalifa, K. Alhooshani, S. Sauro, An in-vitro evaluation of fluoride content and enamel remineralization potential of two toothpastes containing different bioactive glasses, Bio-Medical Materials and Engineering 30 (2019) 487-496.

[82] J. Mesquita-Guimarães, B. Henriques, F. Silva, Bioactive glass coatings, Bio-active Glasses, Elsevier, USA, 2018, pp. 103-118.

[83] S.M. Rabiee, M. Azizian, Effect of zirconia concentration on the growth of nanowires in bioactive glass-ceramic coatings, International Journal of Applied Ceramic Technology 10(1) (2013) 33-39.

[84] S. Ferraris, S. Yamaguchi, N. Barbani, M. Cazzola, C. Cristallini, M. Miola, E. Vernè, S. Spriano, Bioactive materials: In vitro investigation of different mechanisms of hydroxyapatite precipitation, Acta Biomaterialia 102 (2020) 468-480.

[85] J. Massera, 10 - Bioactive glass-ceramics: From macro to nano, in: V. Gua-rino, M. Iafisco, S. Spriano (Eds.), Nanostructured Biomaterials for Regenerative Medicine, Woodhead Publishing, London, 2020, pp. 275-292.

[86] A. Diez-Escudero, M. Espanol, M.-P. Ginebra, Chapter 5 - Synthetic bone graft substitutes: Calcium-based biomaterials, in: H. Alghamdi, J. Jansen (Eds.), Dental Implants and Bone Grafts, Woodhead Publishing, London, 2020, pp. 125157.

[87] M. Manzano, M. Vallet-Regí, Mesoporous Silica Nanoparticles for Drug De-livery, Advanced Functional Materials 30(2) (2020) 1902634.

[88] I. Cacciotti, M. Lombardi, A. Bianco, A. Ravaglioli, L. Montanaro, Sol-gel derived 45S5 bioglass: synthesis, microstructural evolution and thermal behaviour, Journal of Materials Science: Materials in Medicine 23(8) (2012) 1849-1866.

[89] K. Dimitriadis, D. Moschovas, D.U. Tulyaganov, S. Agathopoulos, Develop-ment of novel bioactive glass-ceramics in the $\mathrm{Na}_{2} \mathrm{O} / \mathrm{K}_{2} \mathrm{O}-\mathrm{CaO}-\mathrm{MgO}-\mathrm{SiO}_{2}$ $\mathrm{P}_{2} \mathrm{O}_{5}-\mathrm{CaF}_{2}$ system, Journal of Non-Crystalline Solids 533 (2020) 119936.

[90] O. Rojas, M. Prudent, M.E. López, F. Vargas, H. Ageorges, Influence of At-mospheric Plasma Spraying Parameters on Porosity Formation in Coatings Man-ufactured from 45S5 Bioglass ${ }^{\circledR}$ powder, Journal of Thermal Spray Technology 29(1) (2020) 185-198.

[91] P. Eshghinejad, H. Farnoush, M.S. Bahrami, H.R. Bakhsheshi-Rad, E. Karamian, X.B. Chen, Electrophoretic deposition of bioglass/graphene oxide com-posite on Ti-alloy implants for improved antibacterial and cytocompatible proper-ties, Materials Technology 35(2) (2020) 69-74.

[92] C. Gao, T. Liu, C. Shuai, S. Peng, Enhancement mechanisms of graphene in
nano-58S bioactive glass scaffold: mechanical and biological performance, Scientific Reports 4(1) (2014) 4712.

[93] M. Plewinski, K. Schickle, M. Lindner, A. Kirsten, M. Weber, H. Fischer, The effect of crystallization of bioactive bioglass $45 \mathrm{~S} 5$ on apatite formation and degradation, Dental Materials 29(12) (2013) 1256-1264.

[94] M. Arango-Ospina, Q. Nawaz, A.R. Boccaccini, 9 - Silicate-based nanoc-eramics in regenerative medicine, in: V. Guarino, M. Iafisco, S. Spriano (Eds.), Nanostructured Biomaterials for Regenerative Medicine, Woodhead Publishing, London, 2020, pp. 255-273.

[95] Q. Yao, H. Liu, X. Lin, L. Ma, X. Zheng, Y. Liu, P. Huang, S. Yu, W. Zhang, M. Lin, L. Dai, Y. Liu, 3D Interpenetrated Graphene Foam/58S Bioactive Glass Scaffolds for Electrical-Stimulation-Assisted Differentiation of Rabbit Mesenchy-mal Stem Cells to Enhance Bone Regeneration, Journal of Biomedical Nanotech-nology 15(3) (2019) 602-611.

[96] A.K. Singh, K. Pramanik, A. Biswas, MgO enables enhanced bioactivity and antimicrobial activity of nano bioglass for bone tissue engineering application, Materials Technology 34(13) (2019) 818-826.

[97] N. Karimi, M. Kharaziha, K. Raeissi, Electrophoretic deposition of chitosan reinforced graphene oxide-hydroxyapatite on the anodized titanium to improve bi-ological and electrochemical characteristics, Materials Science and Engineering: C 98 (2019) 140-152.

[98] H. Mokhtari, Z. Ghasemi, M. Kharaziha, F. Karimzadeh, F. Alihosseini, Chitosan-58S bioactive glass nanocomposite coatings on $\mathrm{TiO}_{2}$ nanotube: Structural and biological properties, Applied Surface Science 441 (2018) 138-149.

[99] M. Haftbaradaran-Esfahani, M. Ahmadian, A.H. Nassajpour-Esfahani, Fabri-cation and characterization of porous biomedical Vitallium alloy with $58 \mathrm{~S}$ bioglass coating prepared by sol-gel method, Applied Surface Science 506 (2020) 144959.

[100] J. Faure, R. Drevet, A. Lemelle, N.B. Jaber, A. Tara, H. El Btaouri, H. Ben-hayoune, A new sol-gel synthesis of 45S5 bioactive glass using an organic acid as catalyst, Materials Science and Engineering: C 47 (2015) 407-412.

[101] X.V. Bui, T.H. Dang, Bioactive glass 58S prepared using an innovation solgel process, Processing and Application of Ceramics 13(1) (2019) 98-103.

[102] G. Kaur, V. Kumar, F. Baino, J.C. Mauro, G. Pickrell, I. Evans, O. Bretcanu, Mechanical properties of bioactive glasses, ceramics, glass-ceramics and compos-ites: State-of-the-art review and future challenges, Materials Science and Engineering: C 104 (2019) 109895.

[103] K.C.R. Kolan, J.A. Semon, A.T. Bindbeutel, D.E. Day, M.C. Leu, Bioprint-ing with bioactive glass loaded polylactic acid composite and human adipose stem cells, Bioprinting 18 (2020) e00075.

[104] M.N. Gómez-Cerezo, D. Lozano, D. Arcos, M. Vallet-Regí, C. Vaquette, The effect of biomimetic mineralization of 3D-printed mesoporous bioglass scaffolds on physical properties and in vitro osteogenicity, Materials Science and Engineer-ing: C 109 (2020) 110572.

[105] H.A. Abo-Mosallam, E.A. Mahdy, The influence of MgO on the crystallization behaviour and properties of SrO-rich phosphosilicate glasses, Ceramics International 46(8, Part B) (2020) 12009-12014.

[106] I. Farooq, S. Ali, S. Husain, E. Khan, R.G. Hill, 17 - Bioactive glassesstructure and applications, in: Z. Khurshid, S. Najeeb, M.S. Zafar, F. Sefat (Eds.), Advanced Dental Biomaterials, Woodhead Publishing, London, 2019, pp. 453476.

[107] M. Chavali, P. Palanisamy, M.P. Nikolova, R.-J. Wu, R. Tadiboyina, P.T.S.R.K. Prasada Rao, Chapter 2 - Inorganic composites in biomedical engineer-ing, in: V. Grumezescu, A.M. Grumezescu (Eds.), Materials for Biomedical Engi-neering, Elsevier, USA, 2019, pp. 47-80.

[108] E. Villicaña-Molina, E.A. Aguilar-Reyes, C.A. León-Patiño, R.E. Nuñez-Anita, Preparation of CEL2 glass-ceramic porous scaffolds coated with chitosan microspheres that have a drug delivery function, International Journal of Applied Ceramic Technology 16(5) (2019) 1812-1822.

[109] B. Zhang, J. Huang, R. Narayan, 3 - Nanostructured biomaterials for re-generative medicine: Clinical perspectives, in: V. Guarino, M. Iafisco, S. Spriano (Eds.), Nanostructured Biomaterials for Regenerative Medicine, Woodhead Publishing, London, 2020, pp. 47-80.

[110] C. Domínguez-Trujillo, F. Ternero, J.A. Rodríguez-Ortiz, S. Heise, A.R. Boccaccini, J. Lebrato, Y. Torres, Bioactive coatings on porous titanium for bio-medical applications, Surface and Coatings Technology 349 (2018) 584-592. [111] D. Faria, J.M. Pires, A.R. Boccaccini, O. Carvalho, F.S. Silva, J. Mesqui-ta-Guimarães, Development of novel zirconia implant's materials gradated design with improved bioactive surface, Journal of the Mechanical Behavior of Biomedi-cal Materials 94 (2019) 110-125.

[112] S. Mandal, S. Meininger, U. Gbureck, B. Basu, 3D powder printed tetracal-cium phosphate scaffold with phytic acid binder: fabrication, microstructure 
and in situ X-Ray tomography analysis of compressive failure, Journal of Materials Science: Materials in Medicine 29(3) (2018) 29.

[113] M. Ganjali, A. Yazdanpanah, M. Mozafari, Chapter 8 - Laser deposition of nano coatings on biomedical implants, in: A. Barhoum, A.S.H. Makhlouf (Eds.), Emerging Applications of Nanoparticles and Architecture Nanostructures, Elsevier2018,USA, pp. 235-254.

[114] F. Baino, M.A. Montealegre, G. Orlygsson, G. Novajra, C. Vitale-Brovarone, Bioactive glass coatings fabricated by laser cladding on ceramic acetabular cups: A proof-of-concept study, Journal of Materials Science 52(15) (2017) 9115-9128. [115] Q. Wu, M.L. Mei, X. Wu, S. Shi, Y. Xu, C.H. Chu, Y. Chen, Remineralising effect of 45S5 bioactive glass on artificial caries in dentine, BMC Oral Health 20(1) (2020) 49 .

[116] E. Marin, T. Adachi, M. Zanocco, F. Boschetto, A. Rondinella, W. Zhu, S. Somekawa, R. Ashida, R.M. Bock, B.J. McEntire, B.S. Bal, O. Mazda, G. Pezzotti, Enhanced bioactivity of Si3N4 through trench-patterning and back-filling with Bioglass ${ }^{\circledR}$, Materials Science and Engineering: C 106 (2020) 110278.

[117] F. Baino, J. Minguella-Canela, F. Korkusuz, P. Korkusuz, B. Kankılıç, M.Á. Montealegre, D. los Santos-López, M. Antonia, C. Vitale-Brovarone, In vitro as-sessment of bioactive glass coatings on alumina/zirconia composite implants for potential use in prosthetic applications, International journal of molecular sciences 20(3) (2019) 722.

[118] M.Á. Montealegre, F. Baino, J.L. Arias, J. Minguella, C. Vitale-Brovarone, M. Marshall, Bioactive glass coatings on $\mathrm{Al}_{2} \mathrm{O}_{3}-\mathrm{ZrO}_{2}$ composite substrates by laser cladding for orthopaedic applications, International Congress on Applications of Lasers \& Electro-Optics, Laser Institute of America,USA, 2013, pp. 43-49.

[119] F. Foroutan, B.A. Kyffin, I. Abrahams, A. Corrias, P. Gupta, E. Velliou, J.C. Knowles, D. Carta, Mesoporous Phosphate-Based Glasses Prepared via Sol-Gel, ACS Biomaterials Science \& Engineering 6(3) (2020) 1428-1437.

[120] A. Anand, P. Das, S.K. Nandi, B. Kundu, Development of antibiotic loaded mesoporous bioactive glass and its drug release kinetics, Ceramics International 46(4) (2020) 5477-5483.

[121] F. Iqbal, H. Fatima, 14 - Coating of hydroxyapatite and substituted apatite on dental and orthopedic implants, in: A.S. Khan, A.A. Chaudhry (Eds.), Handbook of Ionic Substituted Hydroxyapatites, Woodhead Publishing, London, 2020, pp. 327-353.

[122] A. Nasar, Hydroxyapatite and its coatings in dental implants, Applications of Nanocomposite Materials in Dentistry, Elsevier, USA, 2019, pp. 145-160.

[123] P. Ning, F. Zhang, L.J. Wang, Y. Zhou, Y.J. Wang, Y.Y. Wu, T. Fu, Sol-gel derived $\mathrm{AgMgO}$ films for antibacterial and bioactive surface modification of niobium metal, Materials Chemistry and Physics 243 (2020) 122646.

[124] B. Liu, G.-y. Xiao, C.-z. Chen, Y.-p. Lu, X.-w. Geng, Hopeite and scholzite coatings formation on titanium via wet-chemical conversion with controlled tem-perature, Surface and Coatings Technology 384 (2020) 125330.

[125] J.R. Martínez, D. Espericueta, G. Guerrero-Serrano, G. Ortega-Zarzosa, E. Espericueta, A.L. Guerrero, Stabilization of $\beta$-carotene embedded in a silica matrix and study of its physical properties, Materials Research Express 7(1) (2020) 015205 .

[126] E.B. Fredj, S. Rousselot, L. Danis, T. Bibienne, M. Gauthier, G. Liang, M.
Dollé, Synthesis and characterization of $\mathrm{LiFe} 1-\mathrm{xMnxPO}_{4}(\mathrm{x}=0.25,0.50,0.75)$ lithium ion battery cathode synthesized via a melting process, Journal of Energy Storage 27 (2020) 101116.

[127] X. Xu, Y. Pan, L. Ge, Z. Shao, Perovskite Materials in Electrocatalysis, in: N.S. Arul, V.D. Nithya (Eds.), Revolution of Perovskite: Synthesis, Properties and Applications, Springer Singapore, Singapore, 2020, pp. 209-250.

[128] D.S. Raghav, S. Kumari, H.K. Singh, G.D. Varma, Structure, magnetism and electrical transport of sol-gel derived La0.30Pr0.30 Ca0.40MnO3: Elucidating consequences of size effect, Journal of Magnetism and Magnetic Materials 497 (2020) 166003.

[129] N.O. Joy-anne, Y. Su, X. Lu, P.-H. Kuo, J. Du, D. Zhu, Bioactive glass coatings on metallic implants for biomedical applications, Bioactive materials 4 (2019) 261-270.

[130] J. Mesquita-Guimarães, L. Ramos, R. Detsch, B. Henriques, M. Fredel, F. Silva, A. Boccaccini, Evaluation of in vitro properties of 3D micro-macro porous zirconia scaffolds coated with $58 \mathrm{~S}$ bioactive glass using MG-63 osteoblast-like cells, Journal of the European Ceramic Society 39(7) (2019) 2545-2558.

[131] F. Lin, C. Yan, W. Zheng, W. Fan, C. Adam, A. Oloyede, Preparation of mesoporous bioglass coated zirconia scaffold for bone tissue engineering, Advanced Materials Research, Trans Tech Publ, Switzerland, 2012, pp. 209-215.

[132] M. Faustini, B. Louis, P.A. Albouy, M. Kuemmel, D. Grosso, Preparation of sol- gel films by dip-coating in extreme conditions, The Journal of Physical Chemistry C 114(17) (2010) 7637-7645.

[133] A. Cattini, L. Łatka, D. Bellucci, G. Bolelli, A. Sola, L. Lusvarghi, L. Pawłowski, V. Cannillo, Suspension plasma sprayed bioactive glass coatings: Effects of processing on microstructure, mechanical properties and in-vitro behaviour, Surface and Coatings Technology 220 (2013) 52-59.

[134] V.L. Calvo, M.V. Cabedo, E. Bannier, E.C. Recacha, A.R. Boccaccini, L.C. Arias, E.S. Vilches, $45 \mathrm{~S} 5$ bioactive glass coatings by atmospheric plasma spraying obtained from feedstocks prepared by different routes, Journal of Materials Science 49(23) (2014) 7933-7942.

[135] A. Joulia, G. Bolelli, E. Gualtieri, L. Lusvarghi, S. Valeri, M. Vardelle, S. Rossignol, A. Vardelle, Comparing the deposition mechanisms in suspension plasma spray (SPS) and solution precursor plasma spray (SPPS) deposition of yt-tria-stabilised zirconia (YSZ), Journal of the European Ceramic Society 34(15) (2014) 3925-3940

[136] M.R. Syed, M. Khan, F. Sefat, Z. Khurshid, M.S. Zafar, A.S. Khan, Chapter 17 - Bioactive Glass and Glass Fiber Composite: Biomedical/Dental Applications, in: G. Kaur (Ed.), Biomedical, Therapeutic and Clinical Applications of Bioactive Glasses, Woodhead Publishing, London, 2019, pp. 467-495.

[137] F. Baino, Chapter 16 - Functionally Graded Bioactive Glass-Derived Scaffolds Mimicking Bone Tissue, in: G. Kaur (Ed.), Biomedical, Therapeutic and Clinical Applications of Bioactive Glasses, Woodhead Publishing, London, 2019, pp. 443-466.

[138] J. Chang, Y.L. Zhou, 6 - Surface modification of bioactive glasses, in: H. Ylänen (Ed.), Bioactive Glasses (Second Edition), Woodhead Publishing, London, 2018, pp. 119-143. 